\title{
Vocational Education and Training in Rural Zimbabwe: Attitudes and Opinions of Students, Teachers and Education Inspectors: The Case of Murewa District
}

\author{
Tapiwa Emmanuel Katsande \\ Health, Social Care and Education Anglia Ruskin University, Cambridge, United Kingdom \\ Cambridge Regional College, Cambridge, UK \\ tkatsande@camre.ac.uk
}

\begin{abstract}
The 2008 global economic crisis has seen young people's career and employment prospects dwindle, particularly for those based in rural areas. Governments in both industrialised and developing countries are considering vocational education reform to meet nations' employment and economic needs. Despite renewed interest in VET, the sentiments of students and teachers remain largely unexplored. This study investigated the views and attitudes of students, teachers and education inspectors towards VET in rural Zimbabwe. The findings revealed divergent views. It emerged that most students did not necessarily have negative views of VET, but they were put off by the low status, lack of choice and the lacklustre delivery of VET. Teachers and students alike were sceptical about the role of VET in securing employment. This study will contribute to the on-going review of Zimbabwe's education system and will inform school managers and policy makers on curriculum development and culture change in rural communities and schools.
\end{abstract}

Keywords: Attitudes; perceptions; students' educational aspirations; vocational education and training

\section{Introduction}

Vocational Education and Training (VET) in past and present times has gone through periods of high regard and episodes of scepticism. In developing countries such as Zimbabwe, Ghana and South Africa VET has been characterised by low status and poor attitudes in comparison to academic subjects. This study explores views and attitudes of students, teachers and education inspectors whose voices are rarely heard in educational policy formulation. The value placed on practical subjects (vocational-technical subjects) in comparison to academic subjects will be assessed. The study analyses data from a Murewa district case study research carried out between November 2012 and August 2013. Zimbabwe gained independence from Britain in 1980 and the new majority government immediately set out to redress the social and economic imbalances of the colonial era. The rural areas formerly known as Tribal Trust Lands or Native Reserves were significantly underdeveloped in comparison to urban areas in terms of infrastructure and economic prosperity. The government embarked on rural development programmes and at the core of these programmes was the desire to promote industrial development in the rural areas through setting up industrial and developmental zones known as 'growth points'. Growth points were designed to be economic nuclei for industrial development. Thirty six years after independence, the growth points have not yielded the desired industrial growth and the gap between rural and urban areas had widened. Rural based young people consequently, have remained marginalised with a high rate of unemployment. Many rural young people who do not progress to tertiary education have limited opportunities to make a living in the rural areas. Without a viable industrial base and economic opportunities, coupled with a failing agricultural industry, rural underdevelopment and youth unemployment are bound to continue unabated. This paper is based on a research study that sought to establish or re-establish the role of vocational training in rural Zimbabwe.

The economic hardships that Zimbabwe faced between 2000 and 2008 gave rise to increased poverty and unemployment, and the rural areas were badly affected. Rural young people were hit hardest. Many rural young people who fail to achieve five Ordinary Level (O level) subjects cannot progress to further education or training leaving them stuck in the villages without means to a livelihood. This situation has prompted the Zimbabwe government to rethink and consider a review of the education system. Politicians and academics in Zimbabwe are calling for the resurrection of the Caiaphas Nziramasanga Presidential Commission of Inquiry into Education and Training which was launched in 1999 to review the education system. After consultations with educational experts, industrialist and charitable organisations, the Nziramasanga Commission 
recommended radical changes to the education system, the curriculum, the examination system and the funding. Among other recommendations, the commission proposed:

- focussing on developing skills in information and communication technologies;

- introducing vocational education in primary school and vocational training in secondary school;

- providing careers guidance and counselling;

- $\quad$ paying particular attention to underprivileged children, girls, and disabled people (Nziramasanga, 1999).

Regrettably, most of the Nziramasanga Commission's recommendations have not been fully implemented. The former Zimbabwe Education Minister, Coltart and UNESCO-IBE (2010) concurred that the Zimbabwean curriculum was urban based and academically skewed at the expense of the socio-economic needs of the country and those of young people. Coltart lamented the post-independence focus on academic education at the expense of vocational education. This paper seeks the perceptions of students, teachers and education inspectors for policy makers to consider in the review of the education system.

What has been known on the subject and key contributions of this study: Studies on vocational education in Zimbabwe by different scholars found that Zimbabwe's education system required revitalising. Mupinga, Bunnet and Redman (2005) citing Munowenyu (1999) argued that the Zimbabwean school curriculum was inadequate in preparing young people for the world of work. Munowenyu (1999) called for the introduction of basic vocational education in schools in order to produce 'skilled and confident problemsolvers'. UNESCO-IBE (2010) criticised the urban based curriculum for failing to address the country's socioeconomic needs and advocated that it should be reviewed. Over 300,000 young people leave school, college and university every year in Zimbabwe but fail to secure employment. This failure to meet the country's and young people's needs, coupled with declining interest in practical subjects, among other issues, have raised politicians' and academics' concerns over the effectiveness of the education system.

This study sought to contribute to a better understanding of young people and teachers' attitudes towards VET in present-day rural Zimbabwe. The study aims to address some gaps in knowledge identified by politicians, policy makers and academics in the field. A leading politician and former Education Minister, Coltart, raised the issue that primary and secondary school students hardly make any decisions for themselves, instead they rely on their parents for career decisions. A study by Nherera (1994) showed that parents had negative attitudes towards VET and this in turn, influenced young people's attitudes. The career decisions that young people make are therefore not based on professional advice. The Skills for Scotland: a lifelong skills strategy (2007) highlighted the need for research on changing attitudes to VET. In the same vein, Edward, Weedon and Riddell's (2008) called for qualitative research using interviews to:

- seek young people's learning experiences during the transition from school to employment or further education;

- explore young people's attitudes to vocational learning;

- explore parental influence on young people's choices and;

- seek teachers' views of VET.

This study responded to the recommendations by IIEP (2006), UNESCO-IBE (2010), Zimbabwe Education Minister, Coltart (2011), Edward, Weedon and Riddell (2008), OECD (2007) and Rojewski (1997) inter alia. The study contributes new contextual knowledge on attitudes, cultural and institutional experiences of rural vocational learners in rural Zimbabwe. The place of VET and issues affecting young people's career choices were investigated from the perspective of both educators and students. The study offers evidence of differences in views of students, teachers and education inspectors regarding VET. Findings from the study further contribute to understanding of the impact of the lack of Information Advice and Guidance (IAG) for rurally based students. Unlike previous studies that focused on secondary and post-secondary school students alone, this study involved both primary and secondary school students. The place of VET in rural Zimbabwe and attitudes towards it were the main focus of this study in the backdrop of increased rural to urban migration, emigration and economic decline. This study brought to light the plight of primary school students who are leaving primary school ill-prepared for secondary education due to limited knowledge of the range of subjects on offer at secondary school. In this study rural young people had high aspirations for prominent jobs in big cities or other countries despite their deprivation. The current study found that it was 
not much about VET but it was the status and delivery that affected attitudes negatively. This study thus generated new information that is instrumental to the review of the Zimbabwean education system.

Definition of Vocational Education and Training: The term Technical and Vocational Education and Training has been adopted by UNESCO to define formal or informal learning experienced in educational institutions, or in the work place (Catts, Falk and Wallace, 2011). Bello, Danjuma and Adamu (2007) described VET as education that provides practical skills, attitudes, understanding and knowledge of particular occupations in different sectors of economic and social life. In light of this characterisation, this paper explores rural Zimbabwean students' and educators' views of VET.

\section{Literature Review}

Development of VET in Zimbabwe: VET in Zimbabwe during the colonial era was fostered, on one hand, by white Missionaries who wished to raise standards for black people, and on the other, by a colonial government that wanted separate development for blacks (Chinyamunzore, 1995). The colonial government deliberately organised the education curriculum to protect whites from black competition (Chinyamunzore, 1995; Nherera, 1994). In the 1960s the colonial regime introduced a vocationally-oriented secondary school curriculum, the F2 stream, parallel to a more respected academic-oriented F1 stream (MOHET 2005). The F2 stream catered for $35 \%$ of the $50 \%$ black primary school leavers who were classed as less academically oriented (Mupinga, Burnett and Redmann, 2005; Chinyamunzore, 1995). F2 graduates had no prospects for further education or training, instead they were expected to utilise acquired skills back in their rural areas (MOHET, 2005). The colonial curriculum was therefore racially divided and consequently, reviled by black people (Shizha and Kariwo, 2011). Soon after independence the new black majority government abolished the despised F2 system in 1981. Due to its colonial legacy VET was perceived as retrogressive thus the 1980s saw a reduction in emphasis on VET (Chinyamunzore, 1995). Though emphasis shifted back to VET in the 1990s, there remained a general preference for academic education (Maravanyika, 1990). Recent trends in Zimbabwe have shown a dramatic expansion of academic education in comparison to VET. Since 1989 the number of universities has increased from one university enrolling 2000 students to 12 universities enrolling 40,000 students (Kariwo, 2007). Despite the remarkable growth of university provision many young people either fail to meet the entry requirements or cannot afford the tuition fees. Kariwo (2007) found that over 8,000 students annually qualify but fail to enter university.

Vocational Education vs. General Education: VET advocates argue that it produces particular human capital with specific skills needed by industry (Oketch, 2007; Tilak, 2002). Conversely, general education backers uphold its ability to create adaptive universal human capital capable of responding to economic and labour needs (Tilak, 2002). Other scholars have acknowledged the complementary roles of VET and general education. Bello, Danjuma and Adamu (2007) argued that good general education including literacy and numeracy is a prerequisite for successful VET delivery. Present-day employers are demanding occupational skills, together with good basic academic skills (Bello, Danjuma and Adamu, 2007).

Attitudes towards VET: Historically, VET has been viewed negatively by students, parents and society in general (Lai and Maclean, 2011). The OECD (2010) stated that despite its potential to create opportunities, VET was greatly undervalued. Oketch (2007) found that young people and their families in Ghana, Senegal, Seychelles, Tunisia and Zimbabwe, viewed VET as inferior and meant for less academic pupils. Similarly, African Union (2007) and Mureithi (2009) found that many people viewed vocational qualifications as less prestigious and associated them with students who had failed to achieve socially and academically. In this vein, Edward, Weedon and Riddell (2008) recommended more research into the impact of cultural and institutional factors on young people's access to VET.

The role of teachers and the family: Among the factors influencing students' decisions to enrol on courses family members, peers, teachers and careers advisers were found to play significant roles (Edward, Weedon and Riddell, 2008). Many students depend on parents, siblings and friends for advice on career choices (Edward, Weedon and Riddell, 2008). A study by the Edge Foundation revealed that $35 \%$ of parents were prejudiced against VET. The Edge Foundation study also found that one in five young people felt that they had 
been ill-advised by their parents (Edward, Weedon and Riddell, 2008). An investigation into parental influence is therefore pertinent.

Statement of the Problem: The fact that over 300,000 young people who leave school, college and university cannot secure employment in Zimbabwe is a national tragedy. The government nonetheless continues to expand academic education at the expense of VET. The lack of interest in VET was evidenced by the low uptake of practical subjects in recent years. In 1996 it was reported that 167,937 candidates sat 0 level examinations in practical subjects compared to 682,090 in academic subjects (Mufanechiya and Mufanechiya, 2011). In 2013 only 211 candidates registered for music, 4874 for food and nutrition, 1533 for computer studies, 3633 for business studies and just 43 for home management (Nleya, 2014). Despite this scenario the government has over the past decade paid lip service to the recommendations made by the 1999 Nziramasanga Commission of inquiry into education which recommended experiential learning to develop desirable traits and competences (Mupondi and Munyaradzi, 2013). Education ministers have in recent years called for a review of the country's education system.

Research Questions: The research topic for this paper is:

Vocational Education and Training in rural Zimbabwe: attitudes and opinions of students, teachers and education inspectors: The Murewa District Case Study.

The study will provide answers to the following research questions:

- What is the contemporary role of VET in Zimbabwe?

- What are the views and attitudes of young people, teachers and education inspectors towards VET?

- Do students' attitudes change during the transition from primary to secondary school?

- What impact do historical and cultural influences have on students' aspirations and the status of VET?

Context and Rationale: Zimbabwe is among many African countries that have been caught up in an economic meltdown with a huge impact on the youth. Boateng (2012) stressed the importance of transforming VET in line with developments in the job market. However, knowledge of youth attitudes and aspirations vis-à-vis training and careers is limited. Bennell et al. (1999) acknowledged the scarcity of contemporary inquiry into VET in Africa which makes this study a worthy contribution. Internationally, VET has struggled to define and promote its status against academic subjects. Cedefop (2011) maintained that VET has been viewed as a second best option which carries a social stigma in a number of countries. In 2010 the United Kingdom government tasked Professor Wolf to conduct a review of VET. Wolf $(2011,6)$ proclaimed that VET has for a long time been seen as 'the poor relation of academic learning.' In Zimbabwe VET has generated considerable interest among academics and politicians. Shizha and Kariwo (2011), Mupinga, Bunnet and Redman (2005) and Chinyamunzore (1995) concurred that the role of VET in Zimbabwe needs to be redefined. The Minister of Education Coltart (2011) regretted that Zimbabwe's postindependence education system was too academic and fell short of meeting the needs of the youth. Despite the clamour for change in VET, the teachers delivering VET and the students receiving the instruction are not being consulted.

This study is particularly important at a time when Zimbabwe has been subject to considerable social, political and economic turmoil since 2000. Zimbabwe was once dubbed the bread basket of Africa producing a range of crops, livestock and minerals. Political instability and subsequently economic crisis has seen the economy shrinking by approximately $50.3 \%$ (UNESCO, 2015). Many companies have closed down. These developments have led to a sharp rise in poverty, unemployment, infrastructure collapse and a haemorrhage of human resources (UNESCO, 2015). UNESCO (2015) estimated that 3 to 4 million untrained, trained and experienced personnel have left Zimbabwe for neighbouring countries. Despite the fast shrinking employment market, academic and university education continues to be the government's priority while VET remains underfunded and peripheral. It should be noted though that the academically skewed education policy has raised Zimbabwe's literacy rate to great heights. UNESCO reported that Zimbabwe has an estimated literacy rate of $92 \%$ - 97\% representing the highest in Africa (Munjanganja and Machawira, 2015). Paradoxically, Zimbabwe also has the highest unemployment rate in the world. The unemployment rate was estimated at $80 \%$ in 2005 rising to $95 \%$ by 2009 (CIA World Factbook, 2016; Statista, 2016). An analysis of the plight of young people caught up between a national jeopardy and a constantly changing vocational sector 
is a worthy contribution to the VET agenda. As Zimbabwe's policy makers and educators seek to overhaul the education system to address young people's aspirations and the country's labour needs, this study particularly offers different perspectives for policy makers' consideration. The study raises important issues regarding the dissonance between teachers and education inspectors regarding VET delivery. The research makes recommendations for addressing the status of VET, attitudinal change and careers guidance for students. This paper is an empirical contribution to ongoing discussions on the role of VET in Zimbabwe. The findings from this study will apprise educational policy makers on the views of students and educators as well as the institutional and cultural status quo of VET.

\section{Methodology}

The case study approach was selected for its ability to gather in-depth information within the delineated unit of Murewa district. Qualitative case studies offer prospects for the exploration and description of phenomena in situ via multiple data sources (Baxter and Jack, 2008). The phenomenon under investigation is attitudes and opinions of VET. The case is students, teachers and education inspectors from Murewa district. Murewa is one of the nine rural districts of Mashonaland East Province. Zimbabwean rural schools follow more or less the same school curriculum and the students share common socio-economic backgrounds. The Murewa district case could therefore provide useful insights into nationwide views. The case study approach combining various methods of data collection was ideal for capturing human experiences to answer the research questions. A quantitative or qualitative method alone would not provide a full understanding of the views and experiences under investigation.

Sampling: Flyvbjerg (2006) emphasised the need for careful selection of cases in order to increase the outcomes of a study. Students were recruited from those who were studying practical subjects and thus possessed first-hand experience of VET. I also selected practical subject teachers and education inspectors who had an understanding of VET curriculum and delivery. Schools that offered a range of practical subjects were also selected to get an appropriate level of information to answer the research questions. The full sample comprised 90 students from three secondary schools, 59 pupils from three primary schools, six practical subject teachers and two education inspectors. The two inspectors were the only practical subject inspectors in the district. The practical subjects included woodwork, fashion and fabrics, food and nutrition, agriculture, building studies and technical graphics. The students were aged between 11 and 17.

Data Collection: Research data was collected using questionnaires which achieved a $100 \%$ response rate. Focus group discussions were then conducted with consenting students. Focus groups were useful for gathering information on collective views and generating a better understanding of participants' experiences and why they held particular views (Morgan, 1998). Semi-structured interview schedules, audio-recorded interviews and open ended questions were used to unravel the research questions.

\section{Data Analysis}

Qualitative data analysis: The research processes of this study were inspired by systematic approaches to data collection and data analysis. Fink (2000) applauded Kvale's (1996) seven stages of the research process: thematising, designing, interviewing, transcribing, analysing, verifying and reporting. The interviews were transcribed into word documents and uploaded into NVivo for coding and identifying themes. Emerging themes from focus groups and interviews were noted and categorised using the open code method (Fink 2000). Commonalities and discords across interviews were then identified and collated.

Quantitative data analysis: Quantitative data from the questionnaires was uploaded into SPSS statistics software. Descriptive statistics were used to analyse data from the questionnaires. Comparisons and unities between primary school and secondary school students' responses were plotted on tables as percentages. Inferential statistics in the form of t-test analysis were used to compare students' interest in subjects. Independent-samples t-tests are used to compare the mean score on some continuous variable, two different groups of people or conditions (Pallant, 2013). I used the independent-samples t-test to explore gender differences in students' interest in all subjects offered. The two variables used were gender and interest in subjects. 
Limitations and Delimitations: All research methods have merits and demerits. The chosen case study approach has often been criticised for lack of generalisabilty. However, the strengths this approach derives from multiple data collection methods have equally been undervalued. The use of various data collection methods in this study was crucial in establishing credibility and trustworthiness of the results. Flyvbjerg $(2011,306)$ argued that case studies are ideal for theory development; providing detailed examination of hypotheses; analysing historical explanations; and developing new questions for investigation. The Murewa case study was strategically selected to increase the reliability and validity of the data. Schools in Murewa district share similar infrastructure and socio-economic backgrounds with rural schools in the rest of the country. These similarities therefore make the findings of this case study applicable and transferrable to other districts. Besides, increasing the number of districts and schools was unlikely to yield any new data.

Theoretical Framework: This study drew inspiration from Functionalist, Conflict and Symbolic Interactionist theories. Functionalists highlighted education's role in sorting and separating students on the basis of merit. Talcott Parsons, Kingsley Davis and Wilbert Moore called this social placement where schools channel the most capable people into the most important occupations to meet societal needs (Margolis, 2002). While functionalists view education's role as that of creating order in society, conflict theorists see education as preserving privileges of the elite and subduing the lower classes into subservient workers (Thompson 2013). The process of training pupils to accept their social class is referred to by conflict theorists as the hidden curriculum. Samuel Bowles and Herbert Gintis (1976) cited by Kentli (2009 p.85) expressed that the hidden curriculum consists of silent but powerful messages that schools send to students about their 'intellectual ability, personal traits, and the appropriate occupational choice.' Symbolic Interactionists maintain that people establish meaning through symbols such as cultural norms and values and act in accordance with their own understanding of those symbols (Sandstrom et al., 2014). Symbolic interactionist theory places emphasis on how student attitudes, dispositions, perceptions, and performance are influenced by teacher expectations (Sandstrom et al., 2014). Thus, the verbal and non-verbal messages that teachers communicate to students have profound impact on their attitudes. Schools are therefore fundamental agents of socialisation through the formal curriculum which includes reading and writing, and the hidden curriculum (Barkan, 2013). Among the several agents of socialisation the family is the most important agent of socialisation for children (Barkan, 2013). Parental traits such as choices, actions, and levels of involvement in their children's education transmit beliefs, mind-sets, and values that shape children's perceptions, abilities and attitudes (Patrikakou, 2008). Family background was consequently a desirable aspect of this study. On the basis of this framework appropriate research questions and suitable data collection methods were selected.

\section{Findings}

Nherera (1994) established that students and parents in Zimbabwe preferred academic education to vocational education due to its historical legacy. Twenty years on, this study presents fieldwork findings on contemporary perceptions of students who by and large have little or no colonial rule misgivings apart from what their parents may impart to them. Family educational background was a strategic starting point for understanding young people's thoughts.

Parents' level of education vis-à-vis students' educational aspirations: Family background has been found to have a strong bearing on young people's attitudes and career choices. Students were asked to indicate their parents' highest educational level. The results showed that $36 \%$ held university degrees, $16 \%$ had A levels, $43 \%$ had 0 levels and 5\% primary or junior certificate education.

Students' educational aspirations: It can be argued that the high levels of parents' education had a bearing on students' desire for university education. Students' responses to the question - Up to what level do you want to continue with your education? - revealed that $92 \%$ of students aspired for university. Students had no intentions of exiting education after 0 or A levels and only 3\% had their sights on VET as illustrated in table 1. These results affirm Davis-Kean and Schnabel's (2001) findings of the close relationship between parental education and children's aspirations. 
Table 1: Students' educational aspirations

\begin{tabular}{lll}
\hline Educational Level & Number & $\%$ \\
\hline O Level & 2 & $1 \%$ \\
A Level & 5 & $4 \%$ \\
Vocational/Technical College & 4 & $3 \%$ \\
University & 129 & $92 \%$ \\
\hline
\end{tabular}

More information was sought by asking students - What do you want to do after your 0 levels? The responses to this question affirmed students' high educational aspirations. In primary schools 54\% aspired for A level. It was interesting to note that in primary school $10 \%$ wished to train at technical colleges and another $9 \%$ were interested in training as technical subject teachers. However, when the same question was presented to secondary school students, there was a shift of interest with $91 \%$ aspiring for A levels, $0 \%$ for technical training and just $2 \%$ interest in training as technical subject teachers as shown in table 2 and figure 1.

Table 2: Students' post 0 level aspirations

\begin{tabular}{|c|c|c|}
\hline $\begin{array}{l}\text { What do you want to do after your } 0 \\
\text { Levels? }\end{array}$ & $\begin{array}{l}\text { Primary school } \\
\text { students }\end{array}$ & $\begin{array}{l}\text { Secondary school } \\
\text { students }\end{array}$ \\
\hline Work & $9 \%$ & $0 \%$ \\
\hline Apprenticeship & $4 \%$ & $6 \%$ \\
\hline Teacher training (Technical Subjects) & $9 \%$ & $2 \%$ \\
\hline Teacher training (Academic Subjects) & $6 \%$ & $0 \%$ \\
\hline Train at a technical college & $10 \%$ & $0 \%$ \\
\hline Self-employment and other & $8 \%$ & $1 \%$ \\
\hline 'A' Levels & $54 \%$ & $91 \%$ \\
\hline
\end{tabular}

Figure 1: Comparison of primary and secondary school students' post 0 level aspirations

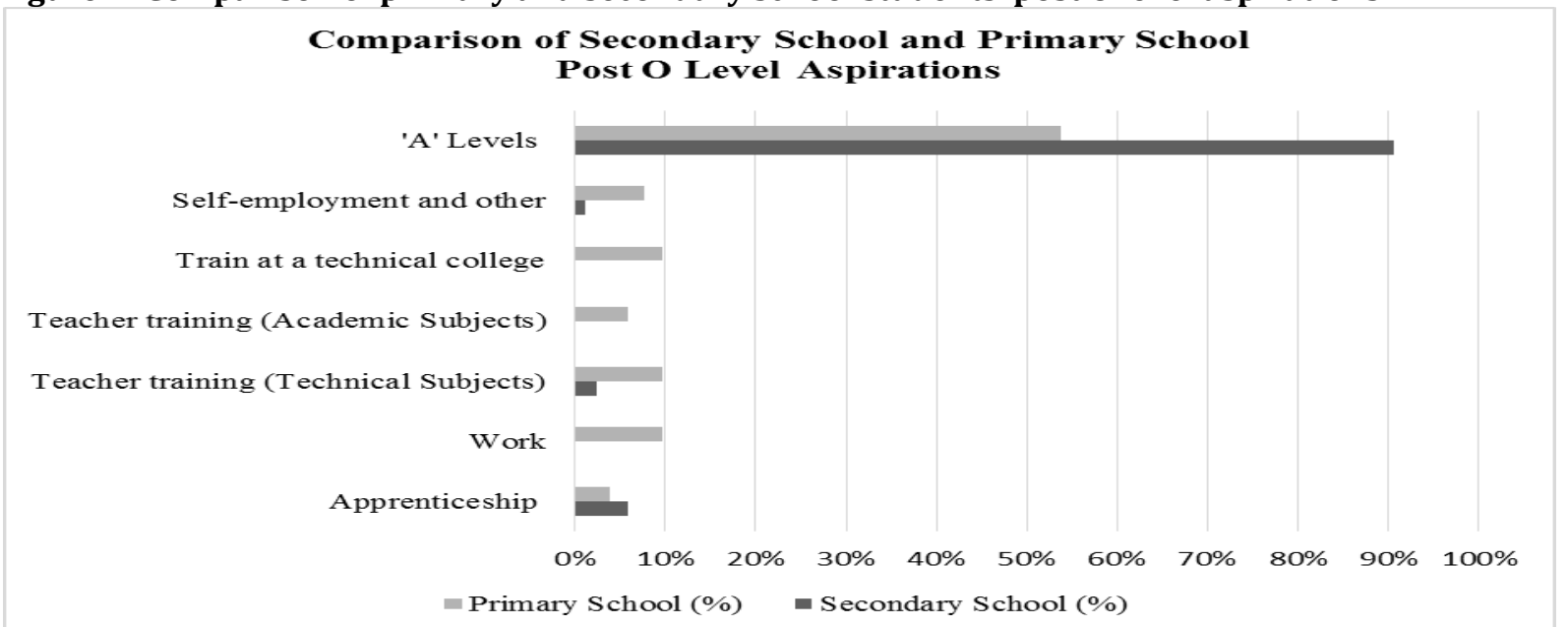

Primary school students showed more interest in technical training, self-employment and seeking work after 0 levels than secondary school students.

Primary School students' interest across all subjects offered: Mathematics, science and English were the most popular subjects amongst primary school students. Students did not respond to agriculture and accounts. When asked in focus groups why they did not rank accounts, students explained that they did not know much about the subject. It was however different with agriculture where students were clear about the subject, but explained that farming was what they had grown up doing so they wished to pursue more prestigious careers. 
Another striking revelation was low interest in physics and chemistry which scored $67 \%$ and $45 \%$ dislikes respectively. Students were aware that these were science subjects but explained that they did not understand the differences between them. Metalwork was also unpopular with $44 \%$ of participants not so sure about their interest in the subject. It was disclosed in the focus groups that lack of knowledge about subjects was the main reason for 'somewhat interested' responses by primary school respondents.

Secondary school students' interest in all subjects: Secondary school respondents as shown in table 4 were more interested in academic subjects than practical subjects. Apart from English literature all academic subjects were popular with students. English, mathematics, science, computers and geography ranked highest while metalwork and woodwork were the least liked scoring $74 \%$ and $69 \%$ dislikes respectively. This was an interesting outcome given that metalwork and woodwork have the potential for small scale business enterprise or rural employment/self-employment. Agriculture which is the mainstay of the rural economy had $38 \%$ of participants having a lukewarm feeling towards the subject. Nevertheless, $50 \%$ of the secondary school students were very interested in agriculture.

Table 3: Primary School students' interest across all subjects offered

\begin{tabular}{llll}
\hline \multicolumn{3}{l}{ From the following list, show your level of interest in each of the subjects } \\
SUBJECT & $\begin{array}{l}\text { 1. Not } \\
\text { interested }\end{array}$ & $\begin{array}{l}\text { 2. Somewhat } \\
\text { interested }\end{array}$ & $\begin{array}{l}\text { 3. Very } \\
\text { interested }\end{array}$ \\
\hline English Language & $2 \%$ & $16 \%$ & $83 \%$ \\
Mathematics & $4 \%$ & $4 \%$ & $93 \%$ \\
General Science & $5 \%$ & $13 \%$ & $82 \%$ \\
Shona vernacular & $5 \%$ & $17 \%$ & $78 \%$ \\
Language & & $25 \%$ & $75 \%$ \\
Bible Knowledge & $0 \%$ & $18 \%$ & $71 \%$ \\
History & $11 \%$ & $21 \%$ & $71 \%$ \\
\hline Fashion and Fabrics & $7 \%$ & $17 \%$ & $71 \%$ \\
Woodwork & $13 \%$ & $27 \%$ & $69 \%$ \\
Food and Nutrition & $4 \%$ & $22 \%$ & $67 \%$ \\
\hline Geography & $11 \%$ & $33 \%$ & $58 \%$ \\
Technical Drawing & $8 \%$ & $44 \%$ & $48 \%$ \\
Textile \& Design & $8 \%$ & $57 \%$ & $36 \%$ \\
\hline English Literature & $7 \%$ & $39 \%$ & $35 \%$ \\
\hline Building & $26 \%$ & $27 \%$ & $27 \%$ \\
\hline Chemistry & $45 \%$ & $8 \%$ & $25 \%$ \\
Physics & $67 \%$ & $44 \%$ & $25 \%$ \\
\hline Metalwork & $31 \%$ & $0 \%$ & $0 \%$ \\
\hline Accounts & $0 \%$ & $0 \%$ & $0 \%$ \\
\hline Agriculture & $0 \%$ & & \\
\hline & & & \\
\hline
\end{tabular}

Practical Subjects

Another area of interest was the significantly large percentage of 'somewhat' responses among primary school students across all practical subjects particularly in metalwork, textile and design, food and nutrition, technical drawing and building. The limited knowledge of these subjects was largely due to lack of adequate careers guidance. When asked whether they had attended any careers advice sessions at school the results were as illustrated in table 5 . The $54 \%$ of primary school and $48 \%$ of secondary students who answered yes indicated that the careers advice was mainly through a careers' day where presenters from industry and big firms came into the school once a year. A notable $32 \%$ of secondary school and $46 \%$ of primary school students had not received careers advice. 
Analysis of all participants' interest in all subjects by gender: The SPSS t-test for equality of variances was employed to compare the average level of interest in subjects between boys and girls and to determine whether females had a stronger preference for a subject than boys. The independent-samples t-test made it possible to compare two unrelated groups (in this case females and males). A Sig. value for Levene's test which is equal or less than $0.05 \mathrm{Sig}$ (2-tailed) means that there is significant difference between boys' and girls' interest in a subject as detailed below. If the value is above 0.05 (e.g. 0.06 or 0.10 ) it means there is no significant difference between boys' and girls' interest in the subject (Pallant 2013).

Table 4: Secondary school students' interest in all subjects

\begin{tabular}{llll}
\hline \multicolumn{3}{l}{ From the following list, show your level of interest in each of the subjects } \\
SUBJECT & $\begin{array}{l}\text { 1. Not } \\
\text { interested }\end{array}$ & $\begin{array}{l}\text { 2. Somewhat } \\
\text { Interested }\end{array}$ & $\begin{array}{l}\text { 3. Very } \\
\text { interested }\end{array}$ \\
\hline English Language & $0 \%$ & $10 \%$ & $90 \%$ \\
Computers & $0 \%$ & $12 \%$ & $88 \%$ \\
Mathematics & $5 \%$ & $10 \%$ & $85 \%$ \\
Geography & $2 \%$ & $18 \%$ & $80 \%$ \\
History & $2 \%$ & $22 \%$ & $76 \%$ \\
Accounts & $0 \%$ & $25 \%$ & $75 \%$ \\
General Science & $6 \%$ & $20 \%$ & $74 \%$ \\
Chemistry & $10 \%$ & $17 \%$ & $73 \%$ \\
Physics & $11 \%$ & $18 \%$ & $72 \%$ \\
Shona & $6 \%$ & $30 \%$ & $65 \%$ \\
Bible Knowledge & $25 \%$ & $11 \%$ & $64 \%$ \\
\hline Agriculture & $13 \%$ & $38 \%$ & $50 \%$ \\
Fashion and Fabrics & $43 \%$ & $13 \%$ & $45 \%$ \\
Textile \& Design & $40 \%$ & $19 \%$ & $40 \%$ \\
Technical Drawing & $39 \%$ & $22 \%$ & $39 \%$ \\
\hline English Literature & $33 \%$ & $33 \%$ & $35 \%$ \\
\hline Building & $41 \%$ & $25 \%$ & $34 \%$ \\
\hline Food and Nutrition & $43 \%$ & $29 \%$ & $29 \%$ \\
\hline Woodwork & $69 \%$ & $20 \%$ & $11 \%$ \\
Metalwork & $74 \%$ & $20 \%$ & $6 \%$ \\
\hline & & & \\
\hline
\end{tabular}

Practical Subjects

Table 5: Attendance to careers advice sessions

\begin{tabular}{llllll}
\hline \multicolumn{2}{l}{ Have you attended any careers advice sessions at your school? } \\
& Primary School & $\begin{array}{l}\text { Secondary } \\
\text { School }\end{array}$ & $\begin{array}{l}\text { Primary } \\
\text { School (\%) }\end{array}$ & $\begin{array}{l}\text { Secondary } \\
\text { (\%) }\end{array}$ & School \\
\hline Yes & 32 & 43 & $54 \%$ & $48 \%$ \\
No & 27 & 47 & $46 \%$ & $52 \%$ & \\
Total & 59 & 90 & $100 \%$ & $100 \%$ & \\
\hline
\end{tabular}

Table 6: Levene's test of interest in all subjects by gender

\begin{tabular}{lll}
\hline Subject & $\begin{array}{l}\text { T-test for equality of means } \\
\text { Sig. (2-tailed) }\end{array}$ & $\begin{array}{l}\text { Statistically significant differences } \\
\text { Yes or No }\end{array}$ \\
\hline English & .077 & No \\
Literature & .018 & Yes \\
\hline
\end{tabular}




\begin{tabular}{lll}
\hline Shona & .143 & No \\
General science & .757 & No \\
Physics & .587 & No \\
Chemistry & .146 & No \\
Biology & .167 & No \\
Geography & .437 & No \\
Mathematics & .631 & No \\
History & .117 & No \\
Bible knowledge & .351 & No \\
Metalwork & .243 & No \\
Fashion and fabrics & .000 & Yes \\
Textiles and design & .009 & Yes \\
Food and nutrition & .000 & Yes \\
Woodwork & .466 & No \\
Technical drawing & .065 & No \\
Building & .129 & No \\
Agriculture & 1.000 & No \\
Accounts & .629 & No \\
Computers & Could not be computed to standards deviations of both groups are 0 \\
\hline
\end{tabular}

The t-test analysis revealed that there was statistically significant difference in interest in fashion and fabrics, textile and design, food and nutrition and literature. Girls had more interest in these subjects than boys indicating that the gender stereotypes associated with practical subjects still exist.

Students' views on the usefulness of practical subjects: After capturing the students' interests, their views on the usefulness of practical subjects were sought. Students were asked to indicate how useful they felt practical subjects were in fulfilling the goals listed in Table 7 below. The results indicated that primary school students were more convinced than secondary school students that practical subjects were very useful for preparing them for employment. Conversely, fewer primary school students felt that practical subjects were very useful in developing positive attitudes towards manual work or self-employment.

Table 7: Comparison of primary and secondary students' views on the usefulness of practical subjects

\begin{tabular}{|c|c|c|c|}
\hline \multicolumn{4}{|l|}{ Primary School } \\
\hline $\begin{array}{l}\text { How useful do you think practical subjects } \\
\text { fulfil the following goals? }\end{array}$ & Not useful & $\begin{array}{l}\text { Somewhat } \\
\text { useful }\end{array}$ & Very useful \\
\hline (a) Preparing pupils for employment & $2 \%$ & $17 \%$ & $80 \%$ \\
\hline (b) Preparing pupils for apprenticeship & $0 \%$ & $77 \%$ & $23 \%$ \\
\hline $\begin{array}{l}\text { (c) Developing a positive attitude towards } \\
\text { manual work }\end{array}$ & $25 \%$ & $40 \%$ & $35 \%$ \\
\hline (d) Preparing pupils for self-employment & $10 \%$ & $51 \%$ & $38 \%$ \\
\hline Applying theoretical knowledge & $5 \%$ & $21 \%$ & $74 \%$ \\
\hline
\end{tabular}
practically

\section{Secondary School}

How useful do you think practical subjects Not useful fulfil the following goals?

(a) Preparing pupils for employment

(b) Preparing pupils for apprenticeship

$6 \%$

(c) Developing a positive attitude towards manual work

(d) Preparing pupils for self-employment

(e) Applying theoretical knowledge 4\% practically
Somewhat useful

\begin{tabular}{lll} 
Not useful & $\begin{array}{l}\text { Somewhat } \\
\text { useful }\end{array}$ & Very useful \\
$6 \%$ & $41 \%$ & $53 \%$ \\
$6 \%$ & $59 \%$ & $36 \%$ \\
$9 \%$ & $19 \%$ & $72 \%$ \\
$9 \%$ & $25 \%$ & $67 \%$ \\
$4 \%$ & $26 \%$ & $70 \%$ \\
\hline
\end{tabular}




\section{Overview of Focus Group Discussions}

Primary school focus group responses: The majority of primary school students expressed high regard for practical subjects. They felt that practical subjects were crucial for life skills. Most primary school students believed that the practical nature of the subjects made them more interesting than academic subjects. Some felt that practical subjects were very useful for securing employment. Others expressed that they did not like them but felt that practical skills could be useful in retirement or when faced with unemployment.

Secondary school focus group responses: There were mixed views among secondary schools students. Some students were more optimistic about the prospects of practical subjects than others. Students had strong views about how schools and employers viewed practical subjects negatively. They wanted schools to treat practical subjects seriously by offering adequate equipment. Others wanted them to be introduced at primary school. They stressed the need for skilled teachers and expressed displeasure at the denigration of practical subjects. Other students acknowledged that they had low regard for practical subjects due to the low status that was accorded to them. Students disliked practical subject allocation methods based on low academic ability. They disliked the lack of uniform subject allocation criteria. Due to complexities caused by limited resources, teachers tended to use the most convenient methods of selection. Students also expressed dissatisfaction over the limited range of practical subjects; lack of choice; the limited time allocation; and the poor motivation of teachers. Contrary to previous studies that claimed that young people dislike practical subjects, this study has shown that it's not about the subject per se, but how the subject is portrayed, packaged and sold to students.

\section{Teachers' Perceptions}

The status of practical subjects: Teachers were disheartened by students' lack of interest and what they perceived as the government's lukewarm commitment to VET. The teachers expressed that:

- Vocational subjects are lower status since most people prefer white-collar jobs.

- Pupils in rural secondary schools shun VET because of how they are taught.

- Practical subjects are considered as auxiliary subjects. Whilst the government has somehow adopted the Nziramasanga Commission's recommendations, not much is being done on the ground.

- Unqualified teachers are still teaching technical subjects.

The issue of unqualified teachers who were teaching practical subjects was a bone of contention expressed by students and education inspectors. Teachers echoed students' concerns over the lack of choice. A teacher suggested that practical subjects must be introduced at A level to raise their profile. This was seconded by another teacher who stated that after introducing food science at A level, students' and teachers' attitudes at their school improved considerably.

Education Inspectors' Perceptions: The first inspector was highly optimistic that the vocational curriculum provided viable pathways for the majority of school leavers who do not proceed to university. The second inspector conversely felt that the expansion of universities was not in sync with the reality that the majority of school leavers in Zimbabwe do not progress to university. The second inspector observed that:

Not every child is academically gifted. There are some who are technically inclined and therefore, I think it took the government sometime especially after the Nziramasanga Commission to go back and advocate for vocational training...

The inspector advocated for early introduction to practical subjects in order to give learners primary opportunities to experience the subjects. The inspector further supported the idea of schools of excellence with specific inclination to particular subject areas. The inspector added that:

The colonial F2 system had its advantages although people disliked it because it was done for the colonialists' benefit. However, after independence those people who had been educated in the F2's were absorbed into road construction, agriculture, building and so on.

Inspectors' views on teacher proficiency: The inspectors felt that teachers' interest and practical skills in a subject had a huge impact on student motivation. According to the inspectors, school inspection visits 
revealed that some teachers lacked the practical skills which made it difficult for them to impart the skills to their learners. The first inspector observed that:

I think negative attitudes have been brought about by the calibre of teachers who are not competent... for example, a teacher taking kids year after year with a $0 \%$ pass rate...pupils are not going to come to that subject. But in schools where teachers are producing good results you find more numbers of students registering for practical subjects.

The second inspector concluded that:

... for any success in vocational training you must have a flair for it, you must love it.

Besides the results, the teacher must sell the subject.

The inspector also recommended that teacher training colleges should enrol trainees who have studied the practical subject in secondary school to ensure that they have the basic skills and interest in the subject.

Discussion: UNESCO-IBE (2010) found that Zimbabwe's urban based curriculum was not fit for purpose. Correspondingly, educators and politicians in Zimbabwe concur that the education system is not meeting the economic needs of the country. The sentiments of students and teachers captured in this study have not only confirmed the failings identified by UNESCO, but have also revealed ingrained inconsistencies and inequalities within the Zimbabwe education system.

The views and attitudes of students, teachers and Education inspectors towards VET: There is evidence to suggest that teachers' motivation and competency influence student attitudes. An instructor needs to be proficient at the job to be able to instruct the learner effectively. In some cases teachers did not only lack the practical skills, but they were not qualified to teach the subject. Consequently, motivation, quality, standards and safety were being compromised. A dichotomy of views emerged where the inspectors and students held teachers responsible for poor results and negative student attitudes. The inspectors criticised teachers for incompetence and failure to market practical subjects. The teachers complained about the lack of adequate equipment and argued that practical subjects were unmarketable in the face of 'superior' better-funded academic subjects. The teachers were convinced that the misfortunes of VET were engrained in the whole education system where there was inequitable allocation of resources. According to the teachers, lack of resources, lack of choice and limited opportunities for progression were chiefly responsible for VET's poor image. In addition, parental attitudes made it very difficult for them to motivate students. According to the teachers, the situation was exacerbated by the lukewarm attitude paid towards work experience and careers guidance by school managers and the Ministry of Education. The above issues prevailing in schools have a profound effect in shaping attitudes towards VET.

Students' attitudes of VET during the transition from primary to secondary school: This study found that attitudes tend to differ between different age groups and different school environments. Primary school students' perceptions differed from those of secondary school students. The evidence suggests that the number of practical subjects on offer in a school influenced the general attitude and status of practical subjects. Schools that offered more practical subjects had more positive responses than those that offered a limited number of practical subjects. It can be argued that the more students are acquainted with practical subjects, the better the attitudes. It can also be argued that the presence of more practical subject teachers provides positive role models. Primary school students were more positive about practical subjects than secondary school students. It can be deduced that there are differences in attitudes towards practical subjects between primary and secondary school students. These attitudinal changes can be attributed to differences in school culture and learning environments. This study puts forward the argument that the hidden curriculum in secondary schools plays a significant role in shaping students' attitudes to practical subjects. The sentiments expressed by secondary school students, teachers and the education inspectors exposed a deepseated culture of apathy towards VET in secondary schools. None of the participants was willing to accept responsibility for the state of affairs. Thus, when primary school children enter secondary school they are instantaneously exposed to a contentious environment that transforms their attitudes towards VET.

The primary school students explained in focus groups that they were not familiar with some science and practical subjects. The lack of awareness of such subjects for students who were in their last grade of primary 
education indicates limited exposure and lack of adequate information and guidance. Evidently, students were leaving primary school without sufficient preparation for secondary education which has a major impact on the choices they make. Many students find themselves overwhelmed by the sheer number of new subjects at secondary school. Students have to make a huge leap to studying a combination of new subjects including practical subjects. It was apparent that lack of knowledge or exposure to particular subjects contributed to poor attitudes or lack of interest. Students indicated in focus groups that they did not like subjects like metalwork because they did not know how useful they would be in future. The fact that most practical subjects except home economics are not talked about in primary school means that students get to learn about them at secondary school. As a result, what might be perceived as negative attitudes towards VET may in fact be unfamiliarity rather than disdain.

Secondary school students' responses illustrated that their comments about practical subjects were not necessarily negative. Instead, they wanted improvements in teacher attitudes pointing out that some teachers were disinterested and unskilled. The students clamoured for choice, adequate time and material resources together with courses that could lead to employment. The students yearned for exposure through work experience and school industrial trips. For VET to gain respectable reputation, it must be a subject of choice. Students are likely to succeed when doing subjects they choose and enjoy. Information is the currency of choice, thus careers advice and guidance is vital to give students insights into viable options and choices for the future. Evidently, lack of exposure stifles young people's imagination and the desire to venture into science and vocational fields. The responsibility for the apathy that surrounds VET is complex and cannot be attributed to a single cause or person. The differences in opinion revealed a disconnection between education inspectors and the teachers. The teachers' plight has brought to the fore issues relating to practical subject results, curriculum aptness along with teacher training and teacher supervision implications. The second class status accorded VET struck a chord with both teachers and students who were bewildered by the little value ascribed to VET in comparison to academic education. The education system is therefore unwittingly perpetuating inequalities between professions and replicating colonial prejudices of VET.

The impact of historical and cultural influences on young people's aspirations and the status of VET qualifications: This study has revealed institutional bias against practical subjects. While the abolition the F2 was aimed at integrating vocational and academic education, the education system remains polarised. One teacher lamented that at his school students with lower academic ability were registered for practical subjects while the more able students were enrolled for commercial and science subjects. The historical belief that practical subjects are suited for less academically inclined students still prevails in schools. The education system's hidden curriculum therefore perpetuates the categorisation of students.

The contemporary role of VET in rural Zimbabwe: The review of literature revealed that the last decade saw an unprecedented expansion of university education giving people the impression that university qualifications were the main vehicle for social mobility. While universities are vital for skills development, technology transfer and creation of new knowledge, it can be argued that they are not everyone's choice. Despite the increase in numbers of universities they still cannot absorb all school leavers. With an exponential increase in unemployment, options for young people including university graduates are very limited. Zimbabwe needs to broaden the skills base through widening participation in VET in order to develop new industries.

Making VET a respectable and viable option: The research has highlighted the quagmire that teachers face when placing students in classes. Due to limited resources devising a fair and effective subject allocation criterion is difficult. Both students and teachers felt that the allocation of practical subjects to students with low ability contributed to poor results. This sets in motion a vicious cycle where poor results reinforce students' perceived low ability which in turn leads to the subjects being degraded. Teachers are under pressure to produce high grades which leads to a tendency to focus on academic subjects and teaching to the examinations. Thus rote learning is being promoted at the expense of experiential learning. The status of any product, service or line of business depends on its usefulness, relevance and the value people bestow upon it. The issue of relevance had resonance with both teachers and students. 'Make VET relevant', was one secondary school participant's stark remark. Teachers and students alike felt that the practical subjects on offer were not relevant to their aspirations. Both primary and secondary school students did not feel that 
practical subjects were useful for preparing pupils for apprenticeships or for developing a positive attitude towards manual work. It is therefore not surprising that $97 \%$ of participants would rather seek white-collar jobs in cities or other countries. The education system is consequently failing in its function to transform children into productive members of society.

\section{Implications for Policy and Practice}

Implications for school managers: There are significant challenges for school managers to recognise the significance of interactions that coalesce to shape students' attitudes and career aspirations. The findings from this study point to the need for school managers to:

- invest in professional careers guidance for students including trips and shop floor experience programmes;

- de-stigmatise practical subjects and remove gender stereotypes in VET;

- promote positive school ethos to raise the status of practical subjects through equitable selection criteria and resource allocation;

- promote curriculum diversity in schools to reflect students' diverse talents;

- embed careers guidance and equality of professions in the school curriculum.

School managers should promote positive school ethos for practical subjects.

Implications for Teacher Training and Recruitment: Teacher motivation was found to be a major problem resulting in lack of interest in VET. The lack of qualified practical subject teachers is a major issue that needs to be addressed. Poor teacher motivation, lack of interest and skills were found to be among the major causes of poor student motivation. There are, therefore, implications for teacher training and recruitment. Recruitment of trainee teachers must be rigorous in order to recruit people with the right attitudes, skills, and interest. There should be a deliberate emphasis on the practical aspect in technical teacher training. Experts and technicians who have practical skills should be empowered to train as teachers. There are far reaching policy implications to be drawn from the relationships between: students and their peers; teachers and students; teachers and the education inspectors; education inspectors and curriculum developers; education providers and employers, industry and the government. Efforts have to be made to harmonise these stakeholders' approaches to VET. The status that the key players accord to VET determines the attitudes of young people and their desire to pursue vocational education. School managers should promote positive school ethos for practical subjects. The study revealed a lack of professional careers guidance and lack of opportunities for students to interact with employers and the workplace. Careers guidance ought to be embedded in the school curriculum and school managers need to invest in shop floor experience programmes. In addition, the subject selection process should encourage choice and reflect the relevance of practical subjects.

There are implications for equitable timetabling between academic and vocational subjects. The current focus on academic education has been found to be ineffective in preparing young people for a fast changing world. The recommendations of the Nziramasanga commission should be revisited to explore how the country can produce a diverse and multi-skilled work force that can adapt to the country's contemporary demands. The curriculum should be revised to include concepts that develop critical thinking to enhance young people's ability to adapt. The potential for VET as a viable career option should be promoted more widely. Young people in this study were compelled to think that VET was an option for those who fail in academic subjects and life in general. Policy makers ought to consider VET programmes that are relevant to the modern world in order that they appeal to young people. The issue of VET relevance is a worldwide concern. Morton (2015) expressed that $58 \%$ of general education students and $71 \%$ of vocational education students were pursuing careers that either will not exist in future or will be transformed by automation. Policy makers and curriculum developers therefore ought to seriously consider curriculum changes in accordance with the country's needs and technological advancement to make VET relevant.

Policy makers need to explore new learning and teaching approaches that prepare children for work from early ages. Education Scotland (2015) proposed an educational approach that places emphasis on work 
experience, careers information, advice and guidance and greater access to vocational learning. Education Scotland proposed:

- developing links between schools and colleges with employers;

- engaging with young people, parents and teachers;

- developing children's and young people's knowledge of the world of work;

- providing early careers advice to young people; (Education Scotland, 2015).

Curriculum developers ought to explore interconnected primary and secondary curriculums to promote continuity from primary to secondary school. In addition, secondary and primary school staff and students should collaborate so as to enhance the student experience. Collaborative learning between primary and secondary school students ought to be encouraged to promote peer education and smooth transitions.

A shared vision among professionals: A disconnection between the SDERU researchers' vision for VET and the experiences of the teachers was discernible. The researchers' optimism was not shared by the young people and the teachers in the schools, or by the inspectors. The teachers and inspectors felt that careers guidance was inadequate whereas the research officer was content with the level of careers days and fairs in schools (mainly urban schools). A shared vision among professionals is needed in order to have consistent and equal access to careers guidance for all students. Rurally based students are disadvantaged as regards careers information and options.

\section{Conclusion}

The evidence from this study shows that students disliked the manner by which VET was viewed and delivered. Teachers had strong views on the status given to practical subjects while education inspectors expressed frustrations over the quality of VET delivery in schools. Despite the divergent views, there was general consensus that VET has a place in education and a role in economic development. There were marked differences in opinion between primary and secondary school students. Primary school students were more positive towards VET than secondary school students. This situation can be attributed to the absence of a smooth transition from primary to secondary school. There is no link between the secondary school vocational curriculum and the primary school curriculum. Rote learning in mathematics, English and science in primary school is not preparing students for independent learning in secondary school. It has been established that the contemporary role of VET in rural Zimbabwe depends on its relevance and ability to meet students' expectations. The hidden curriculum has a huge impact on attitudes. Thus the combined effect of parental influence; an academically oriented curriculum; lack of subject choice; lack of professional careers advice; negative school culture and poor teacher motivation weigh heavily against VET as a viable option for students. Fundamental policy and societal changes need to take place to overturn the adversities VET faces in Zimbabwe.

\section{Recommendations}

Perspective transformation: Based on the findings, reframing notions of VET in light of students' and teachers' experiences and attitudes is recommended. Cavanagh, Shaw and Wang (2013) recommended the concept of rural transformation which differs from rural development. While rural development refers to improving physical infrastructure, rural transformation seeks to transform individuals' views of their circumstances. Cavanagh, Shaw, and Wang (2013) dubbed this notion 'perspective transformation.' Perspective transformation occurs when 'individuals take on a whole new way of viewing their community, society, environment and the world' (Cavanagh, Shaw and Wang 2013, 325). This study recommends:

- perspective transformation in rural Zimbabwe to develop new understanding of VET and its potential;

- exploration of innovative teaching methods to suit the new generation of students;

- encouraging skilled technicians to train as teachers;

- introduction of pre-vocational subjects in primary schools to develop children's interest and knowledge of VET; 
- $\quad$ accessible and innovative careers guidance via digital technology.

Rebranding and repackaging VET: Rebranding involves creating a new image of and feel for an existing product. Kapferer $(2012,9)$ asserted that, '...what really makes a name become a brand is the fact that this name commands trust, respect, passion and even engagement.' This study recommends rebranding to create a new brand of VET that is relevant, appealing and accessible to the youth using technology and social media. Schools in partnership with industry should develop effective profile-raising strategies that make public the rewards of VET qualifications and potential earnings.

Acknowledgements: Sincere gratitude to BELMAS who funded my tuition fees for the last two years of this research. Special thanks to Dr. Geraldine Davis and Dr. Jaki Lilly my supervisors at Anglia Ruskin University. I am also grateful to Professor C.M. Nherera who gave me permission to use his research instruments.

\section{References}

African Union. (2000). Meeting of the Bureau of the Conference of Ministers of Education of the African Union. Addis Ababar COMEDAF. Accessed $\quad$ November $16 \quad 2012$. http://www.africaunion.org/root/au/Conferences/2007/May/HRST/2931/TVET_Strategy_english. doc

Barkan, S. E. (2013). Sociology: Understanding and Changing the Social World, Brief Edition, Flat World $\begin{array}{lllll}\text { Knowledge. } & \text { Accessed } & \text { March } & 22 & \end{array}$ http://catalog.flatworldknowledge.com/bookhub/reader/4306?e=barkbrief-1.1-ch03_s03

Baxter, P. \& Jack, S. (2008). Qualitative Case Study Methodology: Study Design and Implementation for Novice Researchers. The Qualitative Report, 13(4), 544-559.

Bello, M. I. Danjuma, I. M. \& Adamu, A. Y. (2007). A Survey of Vocational Training Needs of 15 - 25 Years Old Out-of-School Youths in Bauchi Metropolis. Journal of Career and Technical Education, 23(1), 55-71.

Bennell, P., Bendera, S., Kanyenze, G., Kimambo, E., Kiwia, S., Mbiriyakura, T., Mukyanuzi, F., Munetsi, N., Muzulu, J., Parsalaw, W. \& Temu, J. (1999). Vocational Education and Training in Tanzania and Zimbabwe in the Context of Economic Reform, Education Research Paper No. 28. Department for International Development.

Boateng, C. (2012). Restructuring Vocational and Technical Education in Ghana: The Role of Leadership Development. International Journal of Humanities and Social Science, 2(4), 108 -114.

Catts, R., Falk, I. \& Wallace, R. (2011). Vocational Learning Innovative Theory and Practice Technical and Vocational Education and Training: Issues, Concerns and Prospects. UNESCO-UNEVOC. Accessed August 20 2012. http://www.springerlink.com/content/x71340/front-matter.pdf.

Cavanagh, D., Shaw, G. \& Wang, L. (2013). Technical and Vocational Education and Training, and Skills Development for Rural Transformation. In: UNESCO-UNEVOC International Centre for Technical and Vocational Education and Training, Revisiting global trends in TVET: Reflections on theory and practice: 309-335.

Cedefop (European Centre for the Development of Vocational Training). (2011). Vocational education and training is good for you: the social benefits of VET for individuals 21. [pdf] Luxembourg: Cedefop. Accessed October 15 2012. http://www.cedefop.europa.eu/EN/Files/5517_en.pdf

Chinyamunzore, N. (1995). Devolution and evolution of technical/vocational education curriculum in Zimbabwe. IDATER 1995 Conference, Loughborough: Loughborough University.

CIA. (Central Intelligence Agency). (2016). Zimbabwe Economy 2016 Accessed February 172016. https://www.cia.gov/library/publications/the-world-factbook/fields/2129.html

Coltart, D. (2011). We can't all be intellectuals. Speech to the Greatness Career Conference in Harare delivered $\begin{array}{lllll}\text { on } \quad \text { February } 2011 . & \text { Accessed } & 2012 .\end{array}$ http://www.newzimbabwe.com/news4491e\%20cant\%20all\%20be\%20intellectuals\%20Coltart/ne ws.aspx

Davis-Kean, P. E. \& Schnabel, K. U. (2001). The impact of socio-economic characteristics on child outcomes: the mediating role of parents' beliefs and behaviors. Child Development, under review. In: L. Feinstein, K. Duckworth and R. Sabates, 2004. A model of the intergenerational transmission of educational success. Wider benefits of learning research report 10. London: Institute of Education. 
Education Scotland. (2015). Developing the Young Workforce. Accessed August 8, 2015. http://www.educationscotland.gov.uk/learningandteaching/thecurriculum/dyw/index.asp

Edward, S., Weedon, E. \& Riddell, S. (2008). Attitudes to Vocational Learning: A literature review. Edinburgh: University of Edinburgh Centre for Research in Education, Inclusion and Diversity Scottish $\begin{array}{llllll}\text { Government } & \text { Social } & \text { Research. } & \text { Accessed } & \text { March } & 20\end{array}$ http://www.scotland.gov.uk/Resource/Doc/233621/0063966.pdf.

Fink, A. S. (2000). The Role of the Researcher in the Qualitative Research Process. A Potential Barrier to Archiving Qualitative Data. Forum Qualitative Sozialforschung / Forum: Qualitative Social Research, 1(3), Art. 4.

Flyvbjerg, B. (2006). Five Misunderstandings about Case-Study Research. Qualitative Inquiry, 12(2), 219-245.

Flyvbjerg, B. (2011). Case Study. In: Norman K. Denzin and Yvonne S. Lincoln, eds. The Sage Handbook of Qualitative Research. $4^{\text {th }}$ ed. Thousand Oaks, CA: Sage Publications.

Lauglo, J. \& Lillis, K. (1988). Vocationalising Education. An International Perspective. Oxford: Pergamon Press.

Kapferer, J. (2012). The New Strategic Brand Management: Advanced Insights and Strategic Thinking $5^{\text {th }}$ ed. Croydon: Cogan Page Limited.

Kariwo, M. T. (2007), Widening Access in Higher Education in Zimbabwe. Department of Educational Policy Studies. Harare: Zimbabwe.

Kentli, F. D. (2009). Comparison of Hidden Curriculum. European Journal of educational Studies, 1(2), 83-88.

Kincheloe, J. L. (1995). Toil and Trouble. Good Work, Smart Workers, and the Integration of Academic and Vocational Education. New York, NY: Peter Lang.

Kvale, S. (1996). InterViews - An introduction to qualitative research interviewing. Thousand Oaks, CA: Sage.

Lai, A. \& Maclean, R. (2011). The future of technical and vocational education and training: global challenges and possibilities. International Journal of Training Research, 9(1-2), 2.

Maravanyika, O. E. (1990). Implementing Educational Policies in Zimbabwe. World Bank Discussion Papers no. 91. Africa Technical Department Series.

Margolis, E. (2002). The Hidden Curriculum in Higher Education. London: Routledge.

MOHET (Ministry of Higher and Tertiary Education). (2005). Policy Review Framework Report on the Technical and Vocational Education and Training. February 2005. ZIMDEF/UNESCO. Harare: Zimbabwe.

Mora, M. (2010). Quantitative Vs. Qualitative Research - When to Use Which. Accessed May 20, 2012. http://www.surveygizmo.com/survey-blog/quantitative-qualitative-research/

Morgan, D. L. (1998). The Focus Group Guide Book. London: Sage Publications.

Morton, R. (2015). Two-thirds of students training for jobs that won't exist, The Australian, 24 August, 2015, 12:00am, Accessed May 15, 2015. http://www.theaustralian.com.au/higher-education/twothirds-ofstudents-training-for-jobs-that-wont-exist/news-story/2d2343561f3f8d7c86c98f516052413e

Mufanechiya, T. \& Mufanechiya, A. (2011.) Motivating Zimbabwean secondary school students to learn: A Challenge. Journal of African Studies and Development, 3(5), 96-104.

Mupinga, D. M., Burnett, M. F. \& Redmann, D. H. (2005). Examining the purpose of technical education in Zimbabwe's high schools. International Education Journal, 6(1), 75-83.

Mupondi, J. G. \& Munyaradzi, G. (2013). An Evaluation of the Vocational Technical Approach to Teaching of Art and Music Education: The Case of Masvingo District, Zimbabwe. International Journal of English and Education, 2(3), 482-492.

Munowenyu, E. (1999). The need to offer basic vocational education in Zimbabwe's secondary schools. Zimbabwe Journal of Educational Research, 11(1), 43-57.

Mureithi, G. W. (2009). Technical, vocational education and training in Africa: has it lost its significance? Accessed November 13 2012. http://www.kmafrica.com/book/export/html/2067

Nherera, C. M. (1994). Vocationalisation of Secondary Education in Zimbabwe: A theoretical and empirical investigation. Ph.D. University of London.

Nleya, F. (2014). Promotion of vocational subjects crucial as pass rates plummet. Accessed February 132016. https://www.newsday.co.zw/2014/02/28/promotion-vocational-subjects-crucial-pass-ratesplummet/

Nziramasanga, C. T. (1999). Report of the Presidential Commission of Inquiry into education and training, Harare: Zimbabwe Government.

OECD (Organisation for Economic Co-operation and Development). (2010). Learning for Jobs: Synthesis Report of the OECD reviews of Vocational Education and Training. Accessed April 102012. 
http://www.mskills.com.au/DownloadManager/downloads/Learning\%20for\%20jobs\%20report.pd $\mathrm{f}$

Oketch, M. O. (2007). To vocationalise or not to vocationalise? Perspectives on current trends and issues in technical and vocational education and training (TVET) in Africa. International Journal of Educational Development, 27(2), 220-234.

Pallant, J. (2013). SPSS Survival Manual: A step by step guide to data analysis using IBM SPSS $5^{\text {th }}$ ed., Berkshire: McGraw Hill Education.

Patrikakou, E. N. (2008). The Power of Parent Involvement: Evidence, Ideas, and Tools for Student Success. $\begin{array}{llll}\text { Accessed } & \text { March } & 29 & \end{array}$ http://education.praguesummerschools.org/files/education/patrikakou_2.pdf

Rojewski, J. W. (1997). Effects of economic disadvantaged status and secondary vocational education on adolescent work experience and postsecondary aspirations. Journal of Vocational Education and Training, 14 (1).

Sandstrom, K. L., Lively, K. J., Martin, D. D. \& Fine, G. A. (2014). Symbols, selves, and social reality: A symbolic interactionist approach to social psychology and sociology. $4^{\text {th }}$ ed. New York: Oxford University Press.

Shizha, E. \& Kariwo, M. T. (2011). Education and Development in Zimbabwe: A Social, Political and Economic Analysis, Rotterdam: Sense Publishers.

Statista. (2016). The 20 countries with the highest unemployment. Accessed February 172016. http://www.statista.com/statistics/264656/countries-with-the-highest-unemployment-rate/

Thompson, M. J. (2013). A functionalist theory of social domination. Journal of Political Power, 6(2), 179-199.

Tilak, J. B. G. (2002). Vocational Education and Training in Asia, National Institute of Educational Planning and $\begin{array}{lllll}\text { Administration. New } & \text { Melhi. }\end{array}$ http://www.norrag.org/wg/documents/Vocational_technical_educat.doc.

UNESCO (United Nations Educational, Scientific and Cultural Organization). (2015). Country Programming Document ZIMBABWE 2013 - 2015. Accessed February 152016. http://unesdoc.unesco.org/images/0022/002270/227055e.pdf.

UNESCO-IBE. (2010). Zimbabwe: World Data on Education, 2010/11. 7th ed. UNESCO. Accessed June 25 2011. $\quad$ http://www.ibe.unesco.org/fileadmin/user_upload/Publications/WDE/2010/pdfversions/Zimbabwe.pdf .

Wolf, A. (2011). Review of Vocational Education: The Wolf Report. Accessed June 282013. https://www.education.gov.uk/publications/eOrderingDownload/The\%20Wolf\%20Report.pdf. 